\title{
Social Maladjustment and Criminal Behavior Pattern Changes in Adolescents in Conflict with the Law
}

\author{
Lais Sette Galinari ${ }^{1}$ (D) \\ Rafaelle Carolynne Santos Costa ${ }^{1}$ \\ André Vilela Komatsu ${ }^{1}$ \\ Marina Rezende Bazon ${ }^{1}$
}

\begin{abstract}
Personality aspects that present a risk for criminal conducts are susceptible to changes. This study aimed to identify the profile of adolescents in conflict with the law based on the Social Maladjustment (SM) construct, to describe patterns of criminal conducts, and to verify the continuity and change on these variables, in a longitudinal prospective study. A sample of 78 adolescents answered to the Jesness Inventory - revised in Brazil and to the Questionnaire of Youth Behaviors, at two collection times (W1 and W2). The profiles were identified with latent class growth analysis and the behavior patterns were compared with Student's t test. Two classes were obtained: High SM and Normative SM. At W1, SM high scores were associated to high frequency in the perpetration of crimes and both classes had lower SM at W2. The results point to the possibility of changes in SM and in conduct over time.
\end{abstract}

Keywords: juvenile delinquency, adolescent development, personality

\section{Mudanças em Desadaptação Social e Padrão de Conduta Delituosa de Adolescentes em Conflito com a Lei}

\begin{abstract}
Resumo: Aspectos de personalidade que representam risco ao envolvimento em condutas delituosas podem sofrer mudanças. Este estudo teve por objetivo identificar perfis de adolescentes em conflito com a lei em relação ao constructo Desadaptação Social (DS), descrever seus padrões de conduta delituosa, verificar continuidade e mudança nessas variáveis com base em delineamento longitudinal prospectivo. Uma amostra de 78 adolescentes respondeu ao Inventário de Jesness - revisado brasileiro e ao Questionário de Comportamentos Juvenis em dois tempos de coleta (W1 e W2). Para identificação dos perfis foi realizada "análise de crescimento de classe latente". Os padrões de comportamento foram comparados com teste $t$ de Student. Obtiveram-se duas classes: DS Alta e DS Normativa. Em W1, altos escores em DS associaram-se com alta frequência no cometimento de delitos e ambas classes apresentaram DS mais baixos em W2. Os resultados apontam possibilidade de modificação de DS e da conduta com a passagem do tempo.
\end{abstract}

Palavras-chave: delinquência juvenil, desenvolvimento do adolescente, personalidade

\section{Cambios en Desajuste Social y en el Patrón de Conductas Criminales en Adolescentes en Conflicto con la ley}

\begin{abstract}
Resumen: Los aspectos de la personalidad que presentan un riesgo para las conductas delictivas pueden cambiar. Este manuscrito tuvo como objetivo identificar perfiles entre adolescentes delincuentes con relación al constructo del Desajuste Social (DS), describir sus patrones de conductas delictivas y verificar la continuidad y el cambio en estas variables, a través de un estudio longitudinal prospectivo. Una muestra de 78 adolescentes respondió al Inventario de Jesness - revisado para Brasil y al Cuestionario de Comportamientos Juveniles, en dos tiempos (W1 y W2). Los perfiles se identificaron mediante análisis de crecimiento de clase latente y se compararon con la prueba t de Student. Se encontraron dos perfiles: DS Elevado y DS Normativo. En W1, puntuaciones elevadas en DS estuvieron asociadas a una alta frecuencia de participación en delitos. En W2, las puntuaciones en DS disminuyeron para ambos perfiles. Los resultados indican la posibilidad de cambios en el Desajuste Social a lo largo del tiempo.
\end{abstract}

Palabras clave: delincuencia juvenil, desarrollo del adolescente, personalidad

${ }^{1}$ Universidade de São Paulo, Ribeirão Preto-SP, Brazil

Article derived from the $\mathrm{PhD}$ thesis of the third author under the supervision of the fourth, presented in 2019, in the Graduate Program in Psychology of Faculdade de Filosofia, Ciências e Letras de Ribeirão Preto. Support: This research was carried out with the support of the Research Support Foundation of the State of São Paulo (Fundação de Amparo à Pesquisa do Estado de São Paulo, FAPESP) - Case number 2017/19381-5 and of the Coordination for the Improvement of Higher level personnel (Coordenação de Aperfeiçoamento de Pessoal de Nível Superior, CAPES) - Brazil Funding Code 001.

Correspondence address: Lais Sette Galinari. Universidade de São Paulo. Faculdade de Filosofia, Ciências e Letras de Ribeirão Preto. Departamento de Psicologia. Avenida Bandeirantes, 3900, Ribeirão Preto-SP, Brazil. CEP 14.040-901. E-mail: laissette@gmail.com
The phenomenon of juvenile delinquency comprises the practice of divergent behaviors (such as use of psychoactive substances, conflict with authority figures) and criminal behaviors (such as theft, drug trafficking, robbery) during adolescence (Kazemian, Farrington \& Piquero, 2019). In a developmental perspective, a persistent pattern of these behaviors (marked by high frequency and severity) is associated with the interaction between social and personal factors throughout the development of the individual (Moffitt, 2018). In this perspective, systemic explanatory models, which integrate variables of different natures, are more pertinent to account for the complexity of 
the interactions involved in the emergence and maintenance of behaviors over time (McGee \& Farrington, 2016).

Research studies aimed at developing and testing these models require longitudinal approaches with sophisticated methods of data analysis (Cauffman, Cavanagh, Donley \& Thomas, 2016). However, they do not exclude the need to study some variables separately, in order to favor decision-making about their inclusion/exclusion from the larger model. This understanding can also favor the proposition and implementation of intervention protocols with a focus on specific aspects, according to the needs of young people, aiming to test the effectiveness of more focal actions, which also contributes to scientific knowledge by refining the understanding about variables of interest.

There is evidence that some personal variables in terms of personality may favor the perpetration of crimes, especially in the transition from adolescence to adulthood, a period of identity formation and, consequently, of stabilization of social behaviors(Jolliffe \&Farrington, 2019). Atafirstlevel, referring to personality traits, (Buss \& Plomin, 2015), the tendency to experience negative emotions, psychological malaise and difficulty in controlling one's behavior (impulsivity) are important predictors of juvenile delinquency, according to recent meta-analyses (Vize, Collison, Miller \& Lynam, 2019; Vize, Miller \& Lynam, 2018). These traits are known as "Antisocial Personality" (Bonta \& Wormith, 2013).

At a second level, there are the individual's beliefs, values and attitudes (adaptive patterns), developed from the interaction between their basic dispositions and the environment. Favorable patterns to the violation of rules/laws increase the chances of engaging in criminal behavior (Intravia et al., 2017; McNeeley, Meldrum \& Hoskin, 2018; O'Riordan \& O'Connell, 2014). Conversely, beliefs, values and attitudes that denote the valorization of rules and the importance of impulse control, in the sense of meeting society's expectations, have a negative association with divergent and criminal behavior (Bilsky \& Hermann, 2016; Borg, Hermann \& Bilsky, 2017). These aspects constitute the "Antisocial Cognition" (Bonta \& Wormith, 2013).

These personality characteristics are compatible with the construct of Social Maladjustment, measured by one of the scales of the Jesness Inventory - revised in Brazil (IJ-R-Br), which bears this name. This construct has a multidimensional character and evaluates together aspects related to "Personality and Antisocial Cognition" (Jesness, 2003; Olver \& Stockdale, 2017; Semel, 2016). This is because individuals who score high on this scale show less ability to consider, in a socially approved way, the demands of the environment, presenting pronounced antisocial orientation, hostility towards the other, negative emotionality, and impulsiveness (Jesness, 2003). In addition, diverse evidence indicates that the Social Maladjustment construct contributes to the identification of adolescents who have different levels of criminal engagement (Semel, 2016; Olver \& Stockdale, 2017).

It is considered that the differences among individuals in terms of psychological functioning can be better understood in terms of profiles than in terms of differences among variables (Luyckx, Teppers, Klimstra \& Rassart, 2014). As adolescentoffenders are differentfromeachother, someauthors indicate the importance of identifying and understanding these differences in terms of psychological profiles (Harder, Knorth \& Kalverboer, 2015), understanding that adolescents with different psychological profiles can behave differently over time (El Sayed, Piquero \& TenEyck, 2017).

In order to identify and understand psychological profiles among adolescent offenders, Bazon and Galinari (2017) analyzed data from a sample of 858 judicialized Brazilian adolescents. Through a cluster analysis, they identified three groups significantly different from one another, one with normative psychological functioning, another with moderate levels of antisocial and impulsivity orientation and indicators of anxiety and depression, and a third with a strong antisocial and impulsivity orientation, in addition to hostility towards others. Another recent Brazilian study offers evidence in the same direction. From a sample of 193 adolescents (60 judicialized and 133 non-judicialized adolescents), Komatsu and Bazon (2017) identified five different groups of adolescents and verified that the greater the infraction engagement, the greater the indicators of impulsivity and antisocial values and attitudes. The results obtained were in agreement with those of other international studies, which highlight the existence of this heterogeneity respecting psychological functioning in the population of adolescents in conflict with the law and the need to consider it in the proposal and implementation of psychosocial intervention programs with them (Luyckx et al., 2014).

It is important to highlight that the aforementioned antisocial attitudes and personality aspects - regarding the dimensions of personality and antisocial cognition (alongside with antisocial peers, family and school problems, for example) - are risk factors for persistent delinquency from the dynamic type, that is, susceptible to change (Cuevas, Wolff \& Baglivio, 2019). These changes can be promoted systematically through intervention programs (Cuevas et al., 2017) or due to the changes that take place over time in the individual and in the environment and, therefore, in the interaction itself, susceptible to impact the identity formation during adolescence (Hill \& Edmonds, 2017).

Thus, gathering the evidence that the Social Maladjustment construct encompasses the aspects understood as "Antisocial Personality and Antisocial Cognition" (Bonta \& Wormith, 2013) and that the adolescent offenders, as a heterogeneous group, are different in relation to personality aspects and to the patterns of criminal behavior, this study aimed to identify profiles of adolescents in conflict with the law in relation to the Social Maladjustment (SM) construct, describe their criminal conduct patterns, and verify continuity and change in these variables based on a prospective longitudinal design. The specific objectives of this study were: (1) To identify groups of male adolescents in conflict with the law, in relation to the Social Maladjustment construct of IJ-R-Br; (2) To identify changes and continuities in these groups over 
a period of approximately one and a half year; (3) To identify intra- and inter-group differences, in the two collection periods, in terms of the pattern of criminal conduct.

\section{Method}

\section{Participants}

This study has a prospective longitudinal design, and the data of interest were collected at two different waves (W1 and W2), with a nearly 18-month interval between the two collections. The inclusion criteria were as follows: Male adolescents, in compliance with a socio-educational measure in Ribeirão Preto-SP, aged 15 years old or more. And the exclusion criteria were the following: Adolescents who were not located to carry out the invitation at W2 or who refused to participate in the research at W2. At W1, 118 male adolescents participated, aged 15 to 19 years old, who were in compliance with a socio-educational measure in Ribeirão Preto - SP $(M=17.8 ; S D=0.8)$. At W2, 78 of these same adolescents participated in the research and they were aged 16 to 20 years old $(M=19.2 ; D P=0.9)$. Of the 118 young individuals, 36 were not found and three refused to participate in the new stage of the study.

Thus, this study focuses on data from the sample composed of 78 young individuals who participated in the study both at $\mathrm{W} 1$ and at W2. Of these 78 participating adolescents, at $\mathrm{W} 1,41 \%$ were in probation and $59 \%$ were in a juvenile detention center. According to the Brazilian Socioeconomic Classification Criterion (Critério de Classificação Socioeconômica Brasil, CCSB), the participants were allocated to the following social classes: B1 (2.5\%), B2 (12.7\%), C1 (54.4\%), C2 (25.3\%), and D (5.1\%).

\section{Instruments}

The data used in this study were collected using two instruments.

Inventário de Jesness - Revisado Brasileiro (IJ-RBr); (Costa, Komatsu, Manzi-Oliveira \& Bazon, 2019). This is an adapted and validated version for Brazil of the Jesness Inventory - Revised (Jesness, 2003). It consists of 160 affirmative sentences, to which the adolescent must answer true or false. Different combinations among these items provide scores on 12 different scales - obtained from correction through a sieve of answers and standardized by comparing the $\mathrm{T}$ score. The mean $\mathrm{T}$ score is 50 and the standard deviation is 10 (Jesness, 2003).

The instrument assesses opinions/thoughts/beliefs, attitudes, perceptions/distortions, feelings/emotions, psychological defenses, and also some personality traits more properly associated with criminal conduct, such as impulsivity, sensation seeking, and hostility (Jesness, 2003). The instrument's scales and their respective Cronbach's alpha indexes obtained from a validation with a sample of Brazilian adolescents are as follows:
Social Maladjustment (SM; $\alpha=0.86$ ), Value Orientation (VO; $\alpha=0.82$ ) Immaturity (Im; $\alpha=0.72$ ), Autism ( $\mathrm{Au} ; \alpha=0.75$ ) Alienation (Al; $\alpha=0.70$ ), Manifest Aggression (MA; $\alpha=0.81$ ), Withdrawal/Depression (Wd; $\alpha=0.70$ ) Social Anxiety (SA; $\alpha=0.54$ ), Repression (Rep; $\alpha=0.42$ ) Denial (Den; $\alpha=0.65)$, Conduct Disorder (CD; $\alpha=0.73$ ), and Oppositional Defiant Disorder (COD; $\alpha=0.70)$. The IJ-R also generates a score on the Associability Index (AI), a measure associated with the risk of reincidence, calculated from a combination of the scores of SM, OV, Au, Al, MA, Wd, SA, and Rep (Costa et al., 2019).

In this study, the analyses focused exclusively on data related to Social Maladjustment (SM). As already mentioned, SM assesses the individual's ability to respect the demands of social life and social rules. Individuals who score high on this scale demonstrate an inability to consider in a socially approved manner the demands of the environment, presenting an antisocial orientation, impulsiveness and hostility towards the other.

Questionário de Comportamentos Juvenis (QJC); (Castro, Cardoso \& Agra, 2010). This is an instrument developed by the Juvenile Delinquency Observatory of Escola de Criminologia da Universidade do Porto. The questionnaire aims to collect data on criminal conduct in adolescence, in addition to social and personal aspects associated with juvenile delinquency. This instrument is similar to that used in the Second International Self-Reported Delinquency Study - ISRD-2 (Junger-tas et al., 2009). In this investigation, the analyses focused on the information collected by a set of 20 items that assess antisocial conduct, more specifically on self-reported criminal behaviors.

The pre-established categories of crimes covered are the following: drug trafficking, handling stolen goods, damage, personal injury, animal abuse, feud, theft, and robbery. The crimes against people (personal injury and theft) were considered violent crimes. For each type of crime, the questions investigate whether the participant had ever done it, regardless of having been arrested by the police, the age of the first manifestation, and the number of times in the last year. The data collectedallow assessing "the age at the beginning of the manifestation of criminal behavior" - which is the earliest age declared when having committed a crime, the "diversity of crimes/ violent crimes already committed" - which is the sum of different types of crimes/violent crimes reported and "total of crimes committed in the last year" - which is the sum of the frequency of crimes/violent crimes reported regarding the last year.

In a recent study already mentioned, the QCJ was able to properly differentiate groups of adolescents in relation to different levels of infraction engagement, with correspondence of psychosocial variables (Komatsu \& Bazon, 2017). Moreover, the method of self-reported delinquency has been compared and considered superior to the official crimes' records, with regard to the ability to identify different levels of criminal engagement (Zara \& Farrington, 2020). 


\section{Procedures}

Data collection. Data collection took place individually in a room at the institution where the adolescents were recruited. In this stage of the research (W1), the IJ-R-Br and QCJ instruments were applied in the form of a structured interview.

In the second stage of the research (W2), after nearly 18 months from the first survey, given the information available to contact the adolescents in their homes/ communities (telephone number(s) and/or address), they were contacted in order to invite them to collaborate with the research again. In this stage (W2), as already mentioned, 81 adolescents were located. Of these, three did not accept to participate in this moment. After clarifying the objective, method and ethical aspects of the research, the 78 remaining adolescents were visited and interviewed in their homes. In this second stage, the adolescents answered the same instruments of the first stage (also applied in the form of an structured interview).

Data analysis. To identify the profiles, a "latent class growth analysis" (LCGA), was performed, based on the participants' scores in Social Maladjustment of IJ-R-Br. Then, the classes were characterized in relation to criminal conduct patterns. LCGA is a model with latent categorical variables that represent subpopulations (classes) in a sample, and belonging to each of these subpopulations is inferred from the evaluated variables. This longitudinal model of latent classes assumes that the evolution of the individuals in the same class is similar and, because of that, it can be considered simpler than other models that allow for variability in individuals of the same class. Despite this, it can provide relevant data by identifying different latent evolution patterns (Berlin, Parra \& Williams, 2013).

Furthermore, LCGA is more suitable for working with small samples, as is the case of this study, since the greater the complexity of the model, the larger the sample size needed. Muthén and Muthén (2002) indicate that the required sample size is conditioned by the number of factors evaluated. For example, the authors estimate that at least 40 participants are needed in a model with no missing data and no co-variables, with only one factor, with that number rising to 150 when adding co-variables, and to 250 if there are missing data in the database (Muthén \& Muthén, 2002).

Despite the availability of data on many other variables, the analyses fell only on the IJ-R-Br Social Maladjustment scale, due to the convenience of working with a single variable in LCGA, but also given its theoretical and empirical value. National and international studies indicate that it is one of the JI-R's scales more related to criminal conduct in adolescence (Komatsu \& Bazon, 2017; Olver \& Stockdale, 2017). To perform the analysis, the $\mathrm{T}$ scores on this scale were categorized considering three ranges: (a) T score with a value up to 55 - low/normative SM; (b) T score between 56 and 65 - moderate SM; (c) T score above 65 - high SM.
To define the best model and the number of ideal classes, the AIC and BIC criteria were used. With this analysis, it was intended to identify different classes of psychological functioning in relation to the construct of SM and how these classes behaved with the passage of time. To perform this analysis, the MPlus Software version 6.4 was used. LCGA estimates the percentage of individuals in each class who would be in each of the SM categories assessed at the two measurement times. From this estimate, it was possible to classify the participants in the identified classes, which allowed for their further characterization in relation to other variables of interest. Thus, after the classification of individuals in the classes found according to the response pattern, they were characterized in relation to the patterns of criminal conduct in the two periods (W1 and W2).

This characterization occurred by calculating the mean and standard deviation and, for the comparison of the means, the Student's $t$ test (for independent samples, when comparing classes and for paired samples, when comparing the same class in the two measured times) was conducted. This procedure was performed using the following variables assessed from the QCJ: (a) age at first crime; (b) diversity of crimes; (c) total frequency of crimes in the last year; (d) diversity of violent crimes; (e) total frequency of violent crimes in the last year. A significance level of 0.05 was adopted. This analysis sought to investigate whether the different classes of psychological functioning have different patterns of criminal conduct. To perform this analysis, the SPSS Software version 22 was used.

\section{Ethical Considerations}

The research project was evaluated and approved by the Ethics Committee on Research with Human Beings of Faculdade de Filosofia, Ciências de Letras de Ribeirão Preto (CAAE No.: 49125415.0.0000.5407). Thus, prior authorization was obtained from the Institutions where they were recruited: NGOs responsible for implementing Probation Programs and a Fundação CASA juvenile detention center, located in Ribeirão Preto. Through these authorizations, the acceptance of the adolescents themselves was sought, attested through the Assent Form, the authorization of the parents or legal responsible, attested through the Free and Informed Consent Form. The participation of adolescents at $\mathrm{W} 2$, insofar as their recruitment took place in the community, occurred after the acceptance of the adolescents, through the signing of a new Assent Form and the authorization of the parents or guardians with the signing of a Free and Informed Consent Form, in the case of those under 18 years old, and acceptance and signature in a specific Free and Informed Consent Form, presented to those who, at this moment, were 18 years old or more. The institutions, the participants and their legal responsible were informed about the objective, method and ethical aspects of the work, so that data collection with the adolescents was only started when all the questions related to the research were clarified. 


\section{Results}

The two classes solution was chosen considering the model adjustment criteria. This was the only possible solution since, due to the sample size, when trying to generate models with more than two classes, the number of parameters generated exceeded the number of observations available for conducting the analysis (sample number). The classes, referring to two subgroups in the sample, were named as "High Social Maladjustment Class" (HSMC) and "Normative Social Maladjustment Class" (NSMC), based on their characteristics in relation to the Social Maladjustment construct. Regarding the distribution of participants in the subgroups, 46 were classified as HSMC (58\%) and 32 participants as NSMC (42\%). At W1, 74\% of the HSMC individuals had a high level in SM, 25\% a moderate level, and $1 \%$ a normative level. At $\mathrm{W} 2$, this distribution changed to $54 \%, 44 \%$ and $2 \%$, respectively. In NSMC, at $\mathrm{W} 1$, there are $4 \%$ of individuals with high SM, $16 \%$ with moderate SM, and $84 \%$ with normative SM. At W2, this distribution changes to $1 \%, 4 \%$ and $96 \%$, respectively. Figure 1 shows the graphical representation of the distribution of individuals in both classes in relation to the three SM scoring categories in the two periods evaluated.

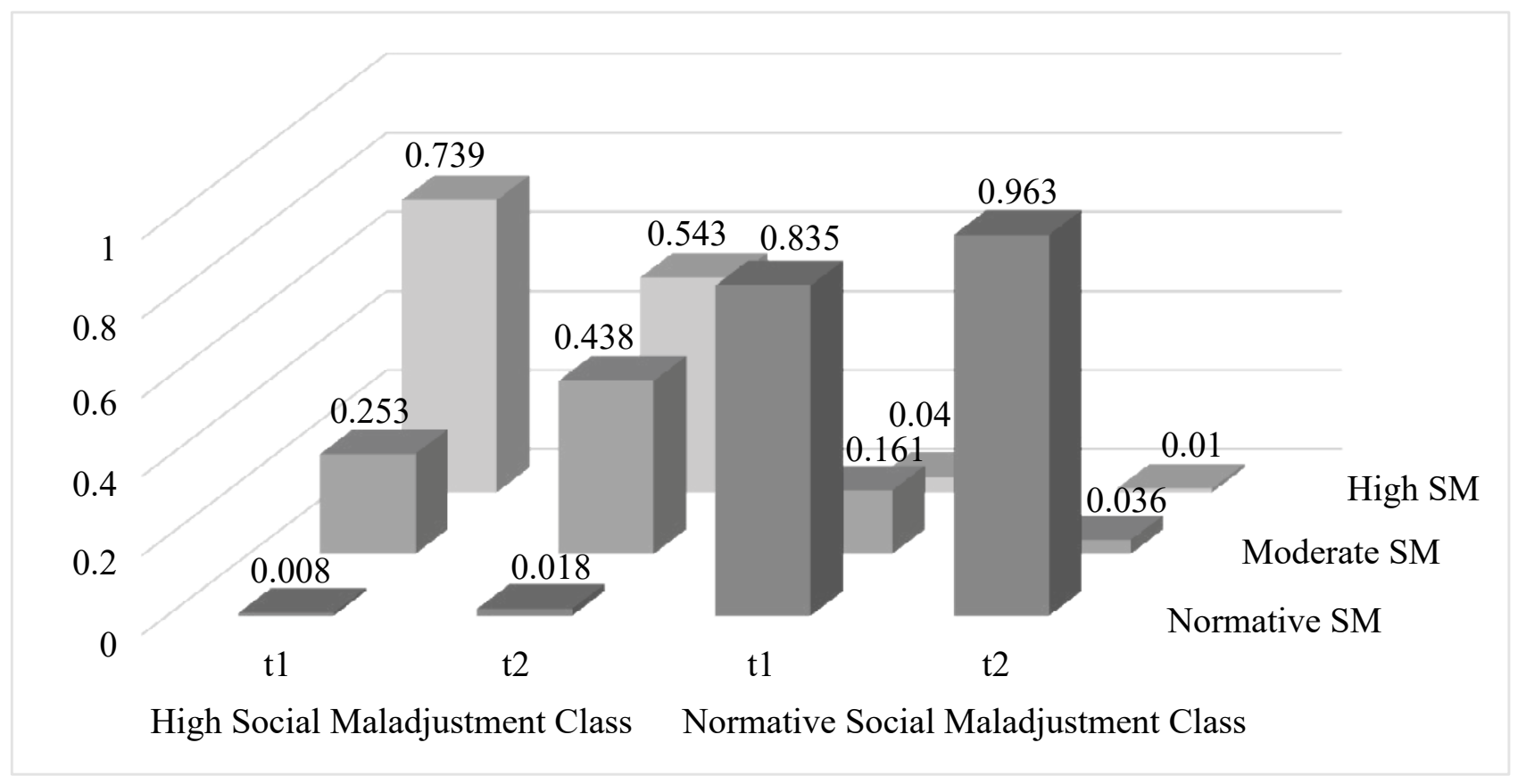

Figure 1. Graphical representation of the identified classes.

In HSMC, the percentage of individuals with scores in the high SM category decreases $(74 \%$ at $\mathrm{W} 1$ and $54 \%$ at W2) and the percentage of individuals with scores in the moderate SM category increases (25\% at W1 and $44 \%$ at W2), while in NSMC the percentage of individuals with scores in the moderate SM category decreases $(16 \%$ at $\mathrm{W} 1$ and $4 \%$ at $\mathrm{W} 2$ ) and the percentage of individuals with scores in normative SM increases $(84 \%$ at $\mathrm{W} 1$ and $96 \%$ at W2).

Table 1 summarizes the characterization of the pattern of criminal conduct in both classes, in average terms. In the comparison between the two classes, from the Student's $\mathrm{T}$ test for independent samples, the means of the frequency of self-reported crimes committed in the last year by the adolescents in the two classes were significantly different at W1. In HSMC, the mean number of crimes was higher than in NSMC. The $t$ and $p$ values presented in Table 1 refer to the comparisons of the Student's $T$ test for independent samples, that is, in relation to the comparisons of the HSMC and NSMC means. The classes do not differ in average terms in relation to the other variables evaluated. When performing the Student's $\mathrm{T}$ test for paired samples with the objective of verifying intraclass differences, at W1 and W2, there was also no evidence of significant changes, on average terms, in relation to the variables evaluated. 
Table 1

Characterization of the Classes in relation to Criminal Conduct

\begin{tabular}{|c|c|c|c|c|c|c|c|}
\hline \multirow[b]{2}{*}{ Time } & \multirow[b]{2}{*}{ Conduct } & \multicolumn{2}{|c|}{$\begin{array}{c}\text { High Social } \\
\text { Maladjustment Class } \\
(\text { HSMC) }\end{array}$} & \multicolumn{2}{|c|}{$\begin{array}{l}\text { Normative Social } \\
\text { Maladjustment Class } \\
\text { (NSMC) }\end{array}$} & \multirow[t]{2}{*}{$t$} & \multirow[t]{2}{*}{$p$} \\
\hline & & $M$ & $S D$ & $M$ & $S D$ & & \\
\hline \multirow{5}{*}{ W1 } & Age at first crime & 12.4 & 1.9 & 12.72 & 1.85 & -0.72 & 0.46 \\
\hline & Diversity of crimes & 5.59 & 3.55 & 5.06 & 3.37 & 0.65 & 0.51 \\
\hline & Freq. of crimes in the last year & 57.35 & 80.56 & 19.19 & 41.43 & 2.73 & 0.01 \\
\hline & Diversity of violent crimes & 1.2 & 1.14 & 1.06 & 1.24 & 0.48 & 0.63 \\
\hline & Freq. of violent crimes in the last year & 8.28 & 24.71 & 1.34 & 3.45 & 1.57 & 0.12 \\
\hline \multirow{5}{*}{ W2 } & Age at first crime & 11.61 & 3.66 & 12.91 & 1.85 & -1.84 & 0.69 \\
\hline & Diversity of crimes & 6.10 & 3.36 & 5.56 & 3.28 & 0.71 & 0.47 \\
\hline & Freq. of crimes in the last year & 46.5 & 56.04 & 26.8 & 68.33 & 1.39 & 0.16 \\
\hline & Diversity of violent crimes & 1.3 & 1.13 & 1.56 & 1.27 & 0.60 & 0.54 \\
\hline & Freq. of violent crimes in the last year & 3.71 & 7.04 & 1.34 & 2.70 & 1.81 & 0.07 \\
\hline
\end{tabular}

Note. $\mathrm{W} 1=$ Wave $1 ; \mathrm{W} 2=$ Wave 2.

\section{Discussion}

This study aimed to identify profiles of adolescents in conflict with the law in relation to the IJ-R-Br Social Maladjustment construct and to describe patterns of criminal conduct, based on self-reported delinquency data, in order to verify continuity and change in these variables, considering the transition from late adolescence to early adulthood. Two distinct classes were identified: High Social Maladjustment Class (HSMC) and Normative Social Maladjustment Class (NSMC). The classes were named according to their characteristics in relation to the score in the Social Maladjustment construct. In both periods, it was verified that most of the adolescents in HSMC had scores in Social Maladjustment indicative of strong antisocial orientation (that is, scores in SM in the moderate and high categories). Likewise, the adolescents who composed NSMC presented, predominantly, in both waves scores in Social Maladjustment in the normative category, that is, scores equivalent to those of the reference youth group of the population, whose data offered the normative parameters of the Inventory.

It was also identified that, at W2 in both classes, there were changes in the personality aspect assessed. For both classes, the mean scores in Social Maladjustment decreased, indicating attenuation of the characteristics measured by the construct (gathered in the definition of the "Personality and Antisocial Cognition" variables). As the literature points out, these changes are likely to happen over time, in the transition from adolescence to adulthood and in subsequent years, showing improvement in psychological functioning (Cuevas et al., 2017; Hill \& Edmonds, 2017). The stimuli that generate this transformation can be internal and external. It is possible that the fact of having fulfilled a socio-educational measure may have influenced the process. Unfortunately, there is no tradition of evaluating the interventions offered by these programs in terms of effectiveness (Soares \& Mendes, 2016). What the most robust longitudinal studies indicate is that, over time, behavioral indicators in young people become more positive, which includes personality aspects, even in those individuals who have more markedly dispositional traits that hinder the self-regulation of behaviors and significant antisocial cognition. In general, these changes in psychological functioning are accompanied by changes also in the pattern of criminal behavior; the reiteration in behavior tends to decrease (Moffitt, 2018).

In the present study, it was verified that the pattern of criminal behavior in HSMC and NSMC, at W1, with regard to the frequency of crimes in the last year variable, was significantly different, in line with what was expected. The HSMC mean in the variable was higher than that presented in NSMC. In addition, the adolescents belonging to HSMC obtained predominantly a score in SM located in the ranges categorized as moderate or high score, in the first moment, whereas the majority of the adolescents in NSMC obtained a score situated in the range categorized as normative score. These results are in agreement with the literature, since the frequency of crimes is an important indicator of the presence of criminal engagement (Morizot \& Kazemian, 2015), associated with antisocial beliefs, values and attitudes (Intravia et al., 2017; O'Riordan \& O'Connell, 2014). They are also in agreement with a recent study, in which high levels of antisocial traits and attitudes are associated with greater criminal engagement, especially with violence (van der Put, Assink \& Gubbels, 2020).

At W2, however, there was no evidence of differences in conduct patterns between classes. It is believed that the considerations regarding $\mathrm{W} 1$ can be valid to explain these results. At the personality level, the most significant changes 
for HSMC were a decrease in the percentage of individuals with high SM scores and an increase in the percentage of individuals with moderate SM scores. For NSMC, the percentage of individuals with moderate SM scores decreases and the percentage of individuals with normative SM scores increases. In other words, over time, all of them have better measures with a decrease in SM scores. The change in SM in young people from HSMC (from a high to a moderate score) was accompanied by a change in the pattern of criminal conduct, in terms of the frequency of crimes committed, which brought them closer, in average terms, to the young individuals in NSMC, regarding the frequency of crimes in the last year. This would explain why these adolescents present a different frequency at W1 and similar at W2, since it is expected, according to data in the literature, that the decrease in SM is accompanied by a decrease in the severity of the conduct pattern (Costa et al., 2019; Semel, 2016), which resulted in greater similarity between the groups.

Along with the sample size, a limitation of the present study is that it was not possible to include other variables in the analysis model that may be relevant and that would assist in understanding the results obtained. It is the case of social variables and/or variables that can be considered as protective factors (Noltemeyer \& Bush, 2013). Nonetheless, even though the conditions to expand the scope of analysis have not been in the direction of desirable integrative models, aiming to explain continuities and changes in criminal behavior patterns in young people, based on the technique used (Berlin et al., 2013), the study produced results that support the evidence regarding changes in the personality aspects assessed, as well as in the patterns of criminal conduct, in a positive direction.

Also, regarding the differences between classes, it was expected to find evidence of these in the other variables investigated: age at first crime, diversity of crime, and diversity and frequency of violent crimes (Bonta \& Wormith, 2013). With reference to age of the first crime, the early beginning has been shown to be an indicator of persistent delinquency, often differentiating young people with more severe patterns from those with less serious conduct patterns, which may include frequency and severity of crimes. However, in the same way, young people in the two classes did not differ in relation to the diversity and frequency of violent crimes. They would also be similar in terms of violent crimes in their evolution. Only the total frequency of crimes in the last year was shown to be differently associated with the SM score. An evolution of more lasting conduct (with high frequency) is associated with the maintenance of this pattern of traits and attitudes, explained by a developmental history of accumulation of risk factors in different domains (StojkovskaStefanovska, 2019).

Thus, although inHSMCyoung people havea less antisocial orientation than in NSMC, at W1, their means in engagement indicators - such as age at first crime, general diversity of crime, and diversity and frequency of violent crimes - they did not show evidence of statistically significant differences. This result takes into account the fact that there are manifestations of delinquency that are more supported by social factors, such as the presence of antisocial peers, inappropriate parenting practices and poor school performance (El Sayed et al., 2017) and that, perhaps in NSMC, the conduct pattern of the adolescents is more properly linked to variables of this nature. Longitudinal studies have identified that these adolescents, for whom personality factors are not very pronounced, little associated with criminal behavior, present a conduct pattern limited to adolescence, which in general is reabsorbed in the first years of adult life, even if during adolescence the behaviors are frequent. It is pointed out in the literature that adolescents in this subgroup need interventions different from those that are also characterized by impairments in terms of psychological development and are more likely to persist (Moffitt, 2018). Adolescents with delinquency limited to adolescence in general would benefit more from community follow-up measures, as detention measures may have an impact on their psychological development, an aspect they do not present at a first moment (Barret \& Katsiyannis, 2017). As a result, it is important to have means of assessing judicialized adolescents in terms of behavior patterns, personality and the social context in which they develop, so that programs can plan actions that are adjusted to their needs. There is national and international evidence that adolescent offenders differ in profiles that represent differences in terms of the pattern of criminal conduct and psychological functioning, which even predict to a large extent behavioral development over time (Bazon \& Galinari, 2017; McGee \& Farrington, 2016; Moffitt, 2018).

The studies that sought to identify profiles of adolescent offenders commonly have a larger sample size and find four to six different profiles in relation to the variables of interest (El Sayed et al., 2017; van der Put et al., 2020; Zara \& Farrington, 2020). Thus, it is possible that, in the present study, it was not possible to identify a number of classes with clearer differences in terms of criminal conduct due to the small sample size available for analysis. In addition, a portion of the adolescents who participated at $\mathrm{W} 1$ were not found at W2, which may have decreased the variability in the SM and conduct patterns of the participants. This would explain why no more differences were found regarding the criminal conduct of the adolescents.

Anyway, despite the limitations, the present study contributed by indicating that a variable considered important for the understanding of juvenile delinquency, which is personality (in terms of basic dispositions) and cognition (in terms of adaptive pattern), when markedly antisocial, are associated with a higher frequency of crimes. These characteristics, however, change over time and are accompanied by changes in the pattern of criminal conduct. The results also confirm the ability of the SM scale of the IJ-R-Br to evaluate these characteristics, showing that the instrument is a tool capable of evaluating attitudinal changes of adolescents in the context of the socio-educational system, which is a subject that deserves attention in future research studies, with larger samples, aiming at a better understanding of the complex phenomenon of juvenile delinquency. 


\section{Referências}

Barrett, D. E., \& Katsiyannis, A. (2017). The Clemson Juvenile Delinquency Project: Major findings from a multi-agency study. Journal of Child and Family Studies, 26(8), 2050-2058. doi:10.1007/s10826-017-0714-8

Bazon, M. R., \& Galinari, L. S. (2017). Psychological profiles of Brazilian adolescent offenders. International Annals of Criminology, 55(2), 158-171. doi:10.1017/cri.2018.3

Berlin, K. S., Parra, G. R., \& Williams, N. A. (2013). An introduction to latent variable mixture modeling (part 2): Longitudinal latent class growth analysis and growth mixture models. Journal of Pediatric Psychology, 39(2), 188-203. doi:10.1093/jpepsy/jst085

Bilsky, W., \& Hermann, D. (2016). Individual values and delinquency: On considering universals in the content and structure of values. Psychology, Crime \& Law, 22(10), 921-945. doi:10.1080/1068316X.2016.1202250

Bonta, J., \& Wormith, J. S. (2013). Applying the risk-needresponsivity principles to offender assessment. In L. A. Craig, L. Dixon, \& T. A. Gannon (Eds.), What works in offender rehabilitation: An evidence-based approach to assessment and treatment (pp. 71-93). Chichester, United Kingdom: Wiley-Blackwell.

Borg, I., Hermann, D., \& Bilsky, W. (2017). A closer look at personal values and delinquency. Personality and Individual Differences, 116, 171-178. doi:10.1016/j. paid.2017.04.043

Buss, A. H., \& Plomin, R. (2015). Temperament: Early developing personality traits. New York, NY: Psychology Press.

Castro, J., Cardoso, C., \& Agra, C. (2010). Projecto: Observatório da Delinquência Juvenil. Relatório Final [Project: Youth Delinquency Observatory. Final report]. Escola de Criminologia, Faculdade de Direito da Universidade do Porto. Relatório Final.

Cauffman, E., Cavanagh, C., Donley, S., \& Thomas, A. G. (2016). A developmental perspective on adolescent risktaking and criminal behavior. In A. R. Piquero (Ed.), The handbook of criminological theory (pp. 100-120). Chichester, United Kingdom: John Wiley \& Sons.

Costa, R. C. S., Komatsu, A. V., Oliveira, A. B. M., \& Bazon, M. R. (2019). Avaliação psicológica em delinquência juvenil: Precisão e validade do Inventário de Jesness: Revisado brasileiro [Psychological assessment in juvenile offenders: Reliability and validity of Inventário de Jesness: Revisado brasileiro]. Psico (Porto Alegre), 50(3), 32336. doi:10.15448/19808623.2019.3.32336
Cuevas, C., Wolff, K. T., \& Baglivio, M. T. (2017). Selfefficacy, aspirations and residential placement outcomes: Why belief in a prosocial self-matters. Journal of Criminal Justice, 52, 1-11. doi:10.1016/j.jcrimjus.2017.06.006

Cuevas, C., Wolff, K. T., \& Baglivio, M. T. (2019). Dynamic risk factors and timing of recidivism for youth in residential placement. Journal of Criminal Justice, 60, 154-166. doi:10.1016/j.jcrimjus.2018.10.003

El Sayed, S. A., Piquero, A. R., \& TenEyck, M. (2017). Differentiating between Moffitt's developmental taxonomy and silverthorn and frick's delayed-onsetmodels of female offending. Criminal Justice and Behavior, 44(4), 631-650. doi:10.1177/0093854816674759

Harder, A. T., Knorth, E. J., \& Kalverboer, M. E. (2015). Risky or needy? Dynamic risk factors and delinquent behavior of adolescents in secure residential youth care. International Journal of Offender Therapy and Comparative Criminology, 59(10), 1047-1065. doi:10.1177/0306624X14531036

Hill, P. L., \& Edmonds, G. W. (2017). Personality development in adolescence. In J. Specht (Ed.), Personality development across the lifespan (pp. 25-38). Amsterdam, Netherlands: Elsevier Academic Press.

Intravia, J., Gibbs, B. R., Wolff, K. T., Paez, R., Bernheimer, A., \& Piquero, A. R. (2017). The mediating role of street code attitudes on the self-control and crime relationship. Deviant Behavior, 39(10), 1305-1321. doi: 10.1080/01639625.2017.1410611

Jesness, C. F. (2003). Jesness Inventory-Revised: Technical manual. North Tonawanda, NY: MHS.

Jolliffe, D., \& Farrington, D. P. (2019). Personality and other individual influences onoffending. In D. P. Farrington, L. Kazemian, \& A. R. Piquero (Eds.), The Oxford handbook of developmental and life-course criminology (pp. 355-377). New York, NY: Oxford University Press.

Junger-Tas, J., Marshall, I. H., Enzmann, D., Killias, M., Steketee, M., \& Gruszczynska, B. (Eds.). (2009). Juvenile delinquency in Europe and beyond: Results of the second international self-report delinquency study. Springer Science \& Business Media.

Kazemian, L., Farrington, D. P., \& Piquero, A. R. (2019). Developmental and life-course criminology. In D. P. Farrington, L. Kazemian, \& A. R. Piquero (Eds.), The Oxford handbook of developmental and lifecourse criminology (pp. 3-10). New York, NY: Oxford University Press. 
Komatsu, A. V., \& Bazon, M. R. (2017). Personal differences among Brazilian adolescents with distinct levels of engagement in delinquency. International Journal of Criminology and Sociology, 6, 65-74. doi:10.6000/19294409.2017.06.07

Luyckx, K., Teppers, E., Klimstra, T. A., \& Rassart, J. (2014). Identity processes and personality traits and types in adolescence: Directionality of effects and developmental trajectories. Developmental Psychology, 50(8), 21442153. doi: $10.1037 / \mathrm{a} 0037256$

McGee, T. R., \& Farrington, D. P. (2016). Developmental and life-course theories of crime. In A. R. Piquero (Ed.), The handbook of criminological theory (pp. 336-354). Chichester, United Kingdom: John Wiley \& Sons.

McNeeley, S., Meldrum, R. C., \& Hoskin, A. W. (2018). Low self-control and the adoption of street code values among young adults. Journal of Criminal Justice, 56, 118-126. doi:10.1016/j.jcrimjus.2017.07.004

Moffitt, T. E. (2018). Male antisocial behaviour in adolescence and beyond. Nature Human Behaviour, 2(3), 177-186. doi:10.1038/s41562-018-0309-4

Morizot, J., \& Kazemian, L. (2015). Introduction: Understanding criminal and antisocial behavior within a developmental and multidisciplinar perspective. In J. Morizot \& L. Kazemian (Eds.), The development of criminal and antisocial behavior: Theory, research and practical applications (pp. 1-16). Cham, Switzerland: Springer.

Muthén, L. K., \& Muthén, B. O. (2002). How to use a Monte Carlo study to decide on sample size and determine power. Structural Equation Modeling, 9(4), 599-620. doi:10.1207/S15328007SEM0904_8

Noltemeyer, A. L., \& Bush, K. R. (2013). Adversity and resilience: A synthesis of international research. School Psychology International, 34(5), 474-487. doi:10.1177/0143034312472758

Olver, M. E., \& Stockdale, K. C. (2017). Convergent and predictive validity of the Jesness inventory in a sample of juvenile offenders. Assessment, 24(7), 865-884. doi: $10.1177 / 1073191116632335$
O’Riordan, C., \& O'Connell, M. (2014). Predicting adult involvement in crime: Personality measures are significant, socio-economic measures are not. Personality and Individual Differences, 68, 98-101. doi:10.1016/j. paid.2014.04.010

Soares, G. R., \& Mendes, D. F. (2016). A atuação do Psicólogo com adolescentes infratores em medida socioeducativas. [The performance of the Psychologist with adolescent offenders in socio-educational programs.] Psicologia e Saúde em Debate, 2(1), 117-137. doi:10.22289/2446-922X.V2EEA9

Stojkovska-Stefanovska, V. (2019). Attitudes and values of young inmates placed in correctional facility. Journal of Criminology and Criminal Law, 57(3), 7-25. Retrieved from https://www.iksi.ac.rs/rkk_arhiva/rkk_3_2019/ rkk_3_2019.pdf

Semel, R. A (2016). Incorporating the Jesness InventoryRevised (JI-R) in a best-practice model of juvenile delinquency assessments. Journal of Forensic Psychology Practice, 16(1), 1-23. doi:10.1080/15228932.2016.1119516

van der Put, C. E., Assink, M., \& Gubbels, J. (2020). Differences in risk factors for violent, nonviolent, and sexual offending. Journal of Forensic Psychology Research and Practice, 20(4), 341-361. doi:10.1080/24732850.2020.1735248

Vize, C. E., Collison, K. L., Miller, J. D., \& Lynam, D. R. (2019). Using Bayesian methods to update and expand the meta-analytic evidence of the Five-Factor Model's relation to antisocial behavior. Clinical Psychology Review, 67, 61-77. doi:10.1016/j.cpr.2018.09.001

Vize, C. E., Miller, J. D., \& Lynam, D. R. (2018). FFM facets and their relations with different forms of antisocial behavior: An expanded meta-analysis. Journal of Criminal Justice, 57, 67-75. doi:10.1016/j. jcrimjus.2018.04.004

Zara, G., \& Farrington, D. P. (2020). Childhood risk factors for self-reported versus official life-coursepersistent, adolescence-limited, and late-onset offending. Criminal Justice and Behavior, 47(3), 352-368. doi:10.1177/0093854819897705 
Lais Sette Galinari is a Researcher at the United Nations Development Program and a $\mathrm{PhD}$ candidate of the Postgraduate Program in Psychology at Faculdade de Filosofia, Ciências e Letras de Ribeirão Preto, Brazil.

Rafaelle Carolynne Santos Costa is a Psychologist and Master's candidate of the Postgraduate Program in Psychology at Faculdade de Filosofia, Ciências e Letras de Ribeirão Preto, Brazil.

André Vilela Komatsu is a Collaborating Professor at the Sociology Department and a Researcher at the Center for the Study of Violence at Universidade de São Paulo, São PauloSP, Brazil.

Marina Rezende Bazon is an Associate Professor at Faculdade de Filosofia, Ciências e Letras de Ribeirão Preto, Universidade de São Paulo, Ribeirão Preto-SP, Brazil.

\section{Authors' Contribution:}

All authors made substantial contributions to the conception and design of this study, to data analysis and interpretation, and to the manuscript revision and approval of the final version. All the authors assume public responsibility for content of the manuscript.

Received: Mar. 14, 2020

1st Revision: Jun. 17, 2020

2nd Revision: Jul.22, 2020

Approved: Jul. 27, 2020

How to cite this article:

Galinari, L. S., Costa, R. C. S., Komatsu, A. V., Bazon, M. R. (2020). Social maladjustment and criminal behavior pattern changes in adolescents in conflict with the law. Paidéia (Ribeirão Preto), 30, e3040.doi:https://doi.org/10.1590/1982-4327e3040 